\title{
Evaluation of the Physicochemical Parameters of Cow's Fresh Milk in Shkodra
}

\author{
Julia Preka ${ }^{1}$ and Adem Bekteshi ${ }^{2}$ \\ 1. Regional Health Directorate, Shkoder 4000, Albania \\ 2. Department of Biochemistry, University of Shkodra, Shkoder 4000, Albania
}

\begin{abstract}
Milk is universally recognized as complete food, which contains essential components for human nutrition. Physicochemical analysis constitutes an important device that monitors its quality. The purpose of this study was to determine the physicochemical characteristics of fresh cow milk in samples taken in the region of Shkodra and Lezha and compare it to European quality standards. Results of the analyses were statistically processed by the Minitab 17 statistical program. Results showed that there is no significant difference $(P>0.05)$ in fat, protein, lactose and density value, while there is significant difference $(P<0.05)$ in $\mathrm{pH}$, ash\% without fat, freezing point and water value. The results show a stability of physicochemical parameters of milk, with variation according to the region where samples were gathered.
\end{abstract}

Key words: Cow's milk, physicochemical parameters, quality.

\section{Introduction}

Food products of animal origin play an important role in sufficient and balanced nutrition of human beings. Milk and milk products are among the most important food products of animal origin [1]. Milk is universally recognized as complete food, which contains essential components for human nutrition. Milk constitutes an essential part in both family and individual diets. It is a colloidal composition containing water, fat, protein, lactose, minerals and other constituents [2]. Besides its general need for human health, milk proteins also provide amino acids which are needed for proper growth of adults and infants [3]. Varman and Sutherland [4] have explained that lactose makes a major contribution to the colligative properties of milk, such as osmotic pressure, freezing point depression and boiling point elevation [5]. The chemical composition of milk widely determines its nutritious value [2]. Fresh milk varies in composition, structure and properties. The

Corresponding author: Julia Preka, Ph.D. student, research fields: food technology and microbiology, assessment of quality and safety. main factors responsible for its natural variation are genetics, lactation period, cow morbidity and food [2]. Ration is the main factor that affects milk composition, as it is the source of milk constituents, and controls the fermentation process in rumen [6]. Consumers always demands nutritionally enriched milk and dairy products [7]. Dairy product quality starts at the farm, as good dairy products can only be made from good quality raw milk. So milk should have normal composition, should be not adulterated and should be produced under hygienic conditions [8]. Various physical and chemical properties of milk have been reviewed previously [9]. According to World Health Organization (WHO) standards and other scientific works, the quality milk should content $2.6 \%$ fat, $3.5 \%$ protein, $\quad 0.17 \%$ titrable acidity (TA), $7.71 \%$ solids-non-fat (SNF), specific gravity (SG) 1.030, and total bacterial count $1.3 \times 10^{6} \mathrm{CFU} / \mathrm{mL}$. The $\mathrm{pH} 6.6$ ensures the milk freshness at boiling point $100-117^{\circ} \mathrm{C}$ [7]. Cow's milk is produced in higher amounts compared to the milk amount produced by other species in the world. World cow's milk production in 2014 stood at 656 million tones [10]. The quality of 
milk is the primary factor that determines the quality of its products. Physicochemical analysis constitutes an important device that monitors its quality. The production of high quality milk and keeping the herd in good health are the main objectives in primary milk production [11]. Cow's milk is processed into a variety of dairy products, such as butter, cheese cream and so on.

Shkodra district has a Mediterranean climate and a favorable natural potential that enable the development of agricultural, livestock and many other activities [12]. It is ranked the third district for the production of milk on a national scale [13]. The area with the highest production of the milk of cows, sheep and goats in this district is the Lowland of Shkodra [14]. There are several factories and dairies that process milk and manufacture its byproducts in Shkodra and its surrounding areas. The purpose of this study was to determine the physicochemical characteristics of fresh cow milk in samples taken in the region of Shkodra and Lezha, and compare it to European quality standards.

\section{Materials and Methods}

\subsection{Study Area}

Shkodra district occupies an area of $1,631 \mathrm{~km}^{2}$. The main places for the production of cow's milk are the Lowland of Shkodra, the Upland of Shkodra and the area of Lezha. The study sites were selected in a way as to represent these three places. Fig. 1 shows places where samples of fresh cow's milk were collected.

\subsection{Sample Collection}

Samples of fresh cow's milk were collected during the period from January to March 2015. Due to collaboration with factories and dairies in Shkodra and its surrounding areas, it was firstly made possible the identification of the main villages that supply with milk. These villages resulted within the area of this study.

For sampling, $50 \mathrm{~mL}$ polyethylene bottles, previously washed with $30 \% \mathrm{HNO}_{3}$ and distilled water, were used. A total of 32 raw milk samples were collected from 24 villages of the study area in the early

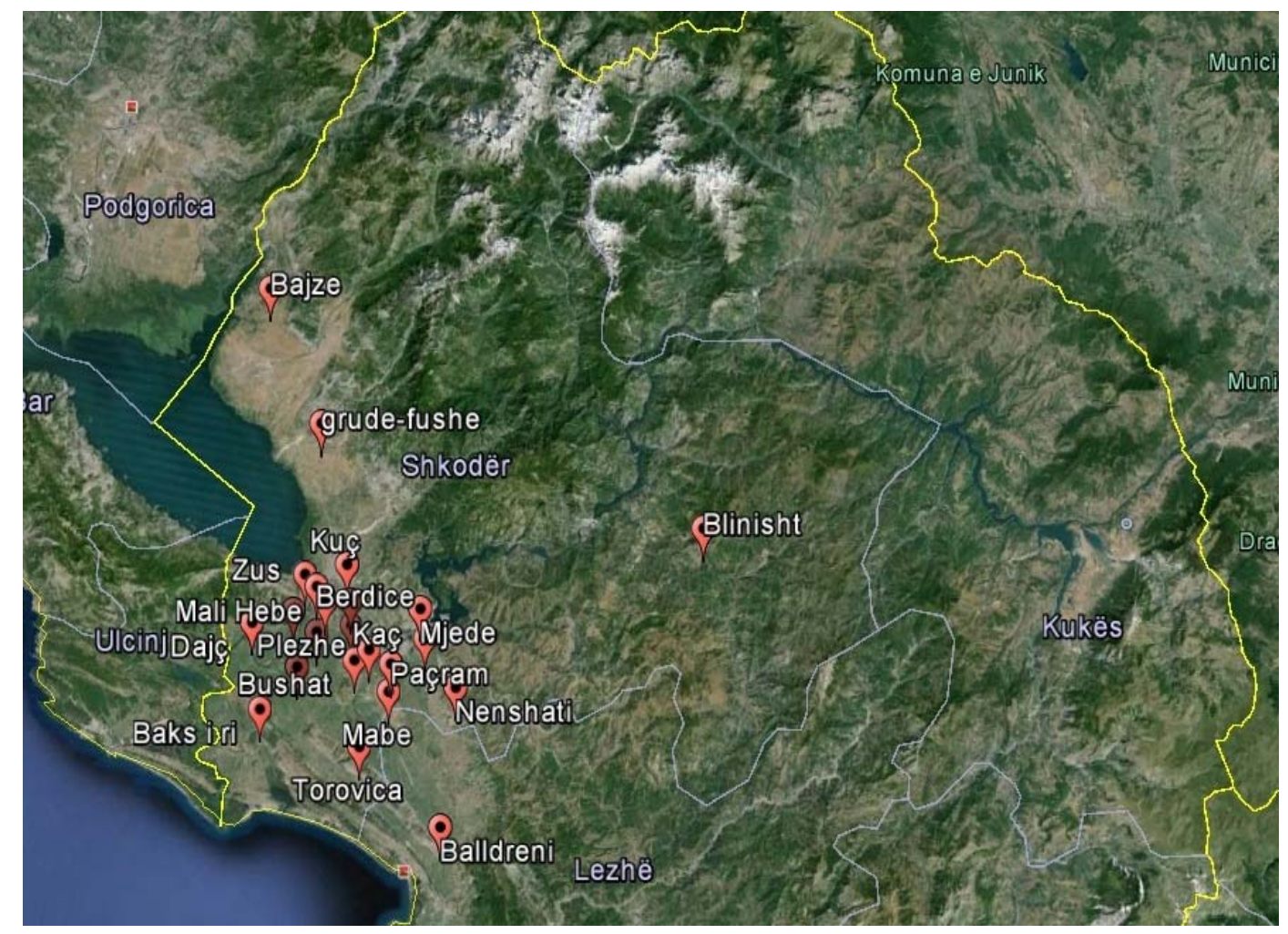

Fig. 1 Sampling points of cow's fresh milk. 
morning. All of the samples were collected according to recommendation of literature and following rigorous procedures [15]. Fresh cow's milk was preliminarily mixed to disperse the milk fat homogeneously before collection of milk sample for physicochemical analysis. Dippers were used in sampling from milk containers. In particular, each milk sample represented more than two takings of milk during morning milking. Samples had labels on each indicating the date and place of their receipt. Samples were kept on ice in flasks to about $4{ }^{\circ} \mathrm{C}$ until they were taken to the laboratory. Samples were analyzed in the laboratory of a high processing capacity milk factory in Shkoder according to regular procedures.

\subsection{Physicochemical Analysis}

The $\mathrm{pH}$ value of the fresh milk samples was determined by a $\mathrm{pH} 315 \mathrm{i} \mathrm{pH}$ meter, which was firstly calibrated in calibration solutions following the instructions of the apparatus. To determine the parameters of fat (\%), protein (\%), lactose (\%) and density $\left(\mathrm{kg} / \mathrm{m}^{3}\right)$, Lactoscan milk analyzer was used [7, 16]. The freezing point $\left({ }^{\circ} \mathrm{C}\right)$ and the amount of water in \% were measured by Funke Cryostar Gerber apparatus (Fig. 2) [7]. Dry matter was calculated on the basis of the freezing point.

\subsection{Statistical Analysis}

Results of the analyses were statistically processed by the Minitab statistical program 17. For samples, statistical parameters were calculated and correlations between parameters were determined.

\section{Results and Discussion}

Descriptive statistics for physicochemical parameters of milk samples are shown in Table 1. pH of milk samples varied from 6.27 to 6.82 with a mean value 6.72. The standard deviation of $\mathrm{pH}(0.1)$ suggests that frequencies were distributed around the mean value. Fat $\%$ content varied from $2.7 \%$ to $5 \%$, with a mean value $3.86 \%$. Protein $\%$ in samples of milk varied from $2.87 \%$ to $3.46 \%$ and the mean value of protein was $3.22 \%$. Lactose $\%$ content varied from $3.57 \%$ to $4.43 \%$, with a mean value of $4.08 \%$. Ash $\%$ (without fat) content varied from $7.42 \%$ to $9.01 \%$, with a mean value of $8.39 \%$. Freezing point $\left({ }^{\circ} \mathrm{C}\right)$ varied from $-0.55{ }^{\circ} \mathrm{C}$ to $-0.74{ }^{\circ} \mathrm{C}$ with a mean value of

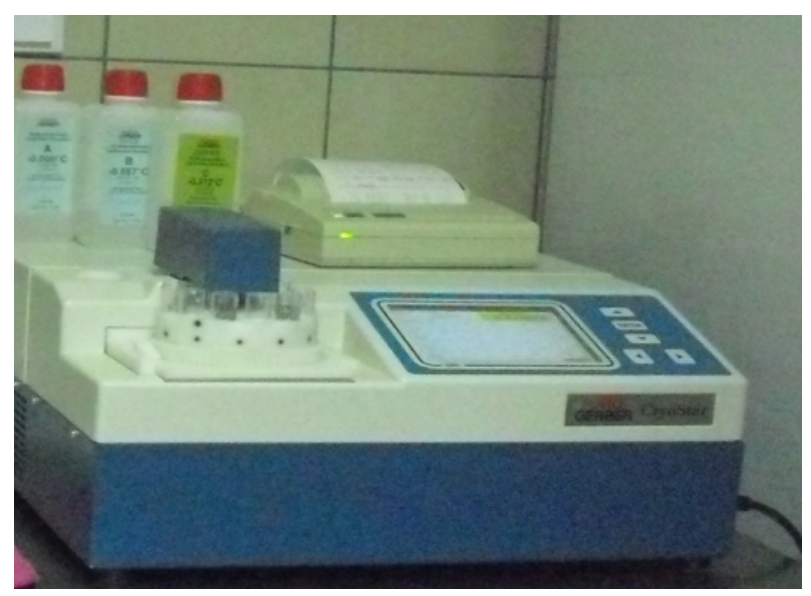

Fig. 2 Funke Cryostar Gerber apparatus.

Table 1 Descriptive statistics for physicochemical parameters of milk from the Upland of Shkodra, Lowland of Shkodra and Lezha.

\begin{tabular}{llllll}
\hline Variable & Mean $\pm \mathrm{SD}$ & Minimum & Median & Maximum & Range \\
\hline $\mathrm{pH}$ & $6.72 \pm 0.10$ & 6.27 & 6.74 & 6.82 & 0.55 \\
Fat $(\%)$ & $3.86 \pm 0.60$ & 2.70 & 4.00 & 4.98 & 2.28 \\
Protein (\%) & $3.22 \pm 0.14$ & 2.87 & 3.21 & 3.46 & 0.59 \\
Lactose (\%) & $4.08 \pm 0.22$ & 3.57 & 4.07 & 4.43 & 0.86 \\
Ash (without fat) $(\%)$ & $8.39 \pm 0.33$ & 7.42 & 8.42 & 9.01 & 1.59 \\
Freezing point $\left({ }^{\circ} \mathrm{C}\right)$ & $-0.52 \pm 0.02$ & -0.55 & -0.52 & -0.74 & 0.08 \\
Density (kg/L) & $1.03 \pm 0.015$ & 1.0255 & 1.0287 & 1.0307 & 0.0052 \\
Added water $(\%)$ & $1.52 \pm 2.40$ & 0.0000 & 0.3000 & 10.300 & 10.300 \\
\hline
\end{tabular}

SD: standard deviation. 
Table 2 Reported values for physicochemical parameters of cow's fresh milk.

\begin{tabular}{lllllllll}
\hline Place & $\mathrm{pH}$ & $\begin{array}{l}\text { Fat } \\
(\%)\end{array}$ & $\begin{array}{l}\text { Protein } \\
(\%)\end{array}$ & $\begin{array}{l}\text { Lactose } \\
(\%)\end{array}$ & $\begin{array}{l}\text { Ash (without } \\
\text { fat })(\%)\end{array}$ & $\begin{array}{l}\text { Freezing point } \\
\left({ }^{\circ} \mathrm{C}\right)\end{array}$ & $\begin{array}{l}\text { Density } \\
(\mathrm{kg} / \mathrm{L})\end{array}$ & Literature \\
\hline Romania & - & 3.75 & 3.23 & - & 8.45 & -0.53 & 1.029 & Mocanu et al., 2011 [17] \\
Romania & - & 3.51 & 3.22 & 4.21 & 8.15 & -0.49 & 1.027 & Tita et al., 2011 [18] \\
Slovakia & - & 3.78 & 3.35 & 4.81 & 8.73 & - & - & Zajác et al., 2012 [19] \\
Czech & - & 3.79 & 3.46 & 4.82 & 8.96 & -0.52 & - & Janštová et al., 2011 [11] \\
Kosovo & 6.45 & 3.58 & 3.36 & 4.75 & 8.90 & -0.57 & 1.028 & Loshi et al., 2013 [20] \\
Albania & 6.72 & 3.86 & 3.22 & 4.08 & 8.39 & -0.52 & 1.030 & This study \\
\hline
\end{tabular}

Table 3 Mean value \pm SD and ANOVA analysis for physicochemical data according to region.

\begin{tabular}{llllll}
\hline Parameter & Upland of Shkodra & Lowland of Shkodra & Lezha & $F$ value & $P$ value \\
\hline $\mathrm{pH}$ & $6.76 \pm 0.05$ & $6.75 \pm 0.04$ & $6.58 \pm 0.23$ & 5.67 & 0.010 \\
Fat (\%) & $3.75 \pm 0.60$ & $3.77 \pm 0.60$ & $4.33 \pm 0.50$ & 1.44 & 0.258 \\
Protein (\%) & $3.25 \pm 0.10$ & $3.20 \pm 0.15$ & $3.27 \pm 0.14$ & 0.51 & 0.609 \\
Lactose (\%) & $4.11 \pm 0.16$ & $4.06 \pm 0.23$ & $4.14 \pm 0.21$ & 0.24 & 0.788 \\
Ash (without fat) (\%) & $8.77 \pm 0.15$ & $8.26 \pm 0.28$ & $8.67 \pm 0.25$ & 7.26 & 0.004 \\
Freezing point $\left({ }^{\circ} \mathrm{C}\right)$ & $-0.54 \pm 0.008$ & $-0.51 \pm 0.015$ & $-0.53 \pm 0.012$ & 7.15 & 0.004 \\
Density (kg/L) & $1.029 \pm 0.0012$ & $1.028 \pm 0.015$ & $1.029 \pm 0.015$ & 0.62 & 0.548 \\
Water (\%) & $0.00 \pm 0.00$ & $2.10 \pm 2.60$ & $0.075 \pm 0.15$ & 7.15 & 0.040 \\
\hline
\end{tabular}

$-0.52{ }^{\circ} \mathrm{C}$. Density $(\mathrm{kg} / \mathrm{L})$ varied from $1.0255 \mathrm{~kg} / \mathrm{L}$ to $1.0307 \mathrm{~kg} / \mathrm{L}$ with a mean value of $1.03 \mathrm{~kg} / \mathrm{L}$. Added water $\%$ varied from $0 \%$ to $10.3 \%$ with a mean value of $1.52 \%$.

Comparison of results in this study to those reported in literature from other authors is presented in Table 2. As seen from Table 2, cow's fresh milk from Albanian farms has higher fat $\%$ values and lower lactose $\%$ values compared to milk analyzed in Romania, Slovakia, Czech Republic and Kosovo. However, this milk has approximate values of protein $\%$, ash $\%$ (without fat), freezing point $\left({ }^{\circ} \mathrm{C}\right.$ ) and density $(\mathrm{kg} / \mathrm{L})$. Protein content in milk analyzed in Albania is equal to that analyzed in Romania, freezing point is equal to that analyzed in the Czech Republic, while density is almost equal to milk analyzed in all other countries.

Table 3 shows the results of ANOVA analysis with milk samples according to region. Samples were classified according to region of collection, i.e., Upland of Shkodra, Lowland of Shkodra and Lezha region.

Mean values of $\mathrm{pH}$ for Shkodra region differ from Lezha region where samples were gathered. ANOVA analysis showed that there were significant differences between $\mathrm{pH}$ of milk gathered in those regions. Mean values of fat $\%$, protein $\%$ and lactose $\%$ content in milk samples according to the regions do not change significantly, indicating that there were not significant differences in fat $\%$, protein $\%$ and lactose $\%$ content $(P$ $=0.258, P=0.609$ and $P=0.788$, respectively) in milk samples gathered in three regions. Ash\% nonfat content varied from the region where samples were gathered. ANOVA analysis showed that there were significant differences $(P=0.004)$ in ash\% without fat in milk samples gathered in three regions. Higher values are encountered in the Upland of Shkodra and Lezha. The Upland of Shkodra is a mountain hilly area, in which soil irrigation system was destroyed, after the 90's, due to political changes in Albania. This brought consumption of more dried food. While the Lowland of Shkodra is a field area characterized by higher water contents and consequently has lower values of nonfat ash $\%$. Water content in samples varied from $0.0 \%$ to $10.3 \%$ with a mean value $1.52 \%$. The highest content of water was found in the Lowland of Shkodra with mean value $2.1 \%$. ANOVA analysis showed the variability in the water content in milk samples depending on the region. 
Fig. 3 shows the mean value and $95 \%$ confidence interval (CI) of physicochemical parameters based on the region were samples were gathered. Changes in the mean value were observable in water content, which was higher in the Lowland of Shkodra. The most varied parameter was water content in the Upland of Shkodra region and Lezhe region.

Fig. 4a shows that there were two components that contribute to the quality of cow milk. Both components explain $80 \%$ variability of the quality of milk based on physicochemical analyses. Fig. $4 \mathrm{~b}$ show the contribution of properties: protein $\%$, lactose $\%$, ash $\%$ and density have positive effect on first factor, while water $\%$ has negative effect in first factor. $\mathrm{pH}$ has positive effect in the second factor, while fat $\%$ has negative effect in second factor.

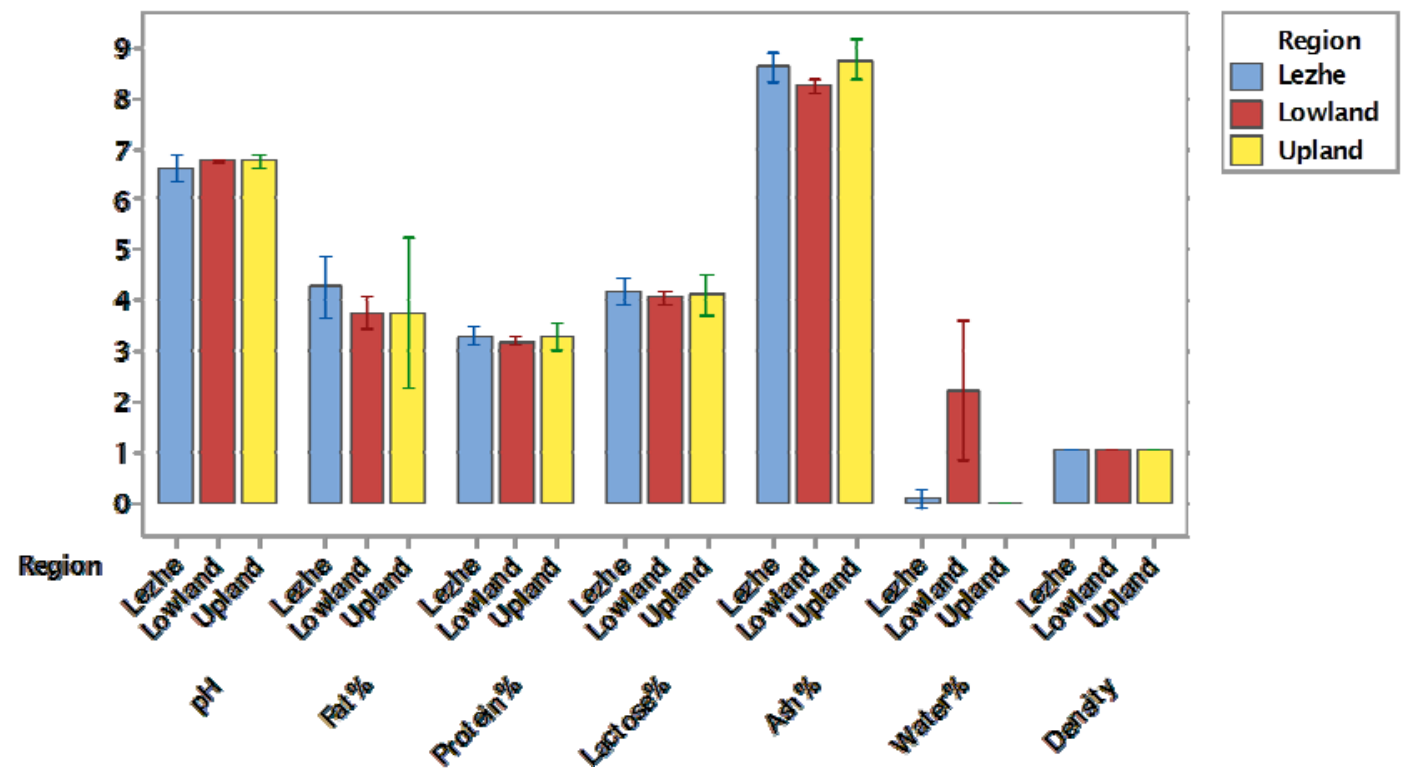

Fig. 3 Mean values of physicochemical properties based on the region. Individual standard deviations were used to calculate the intervals.

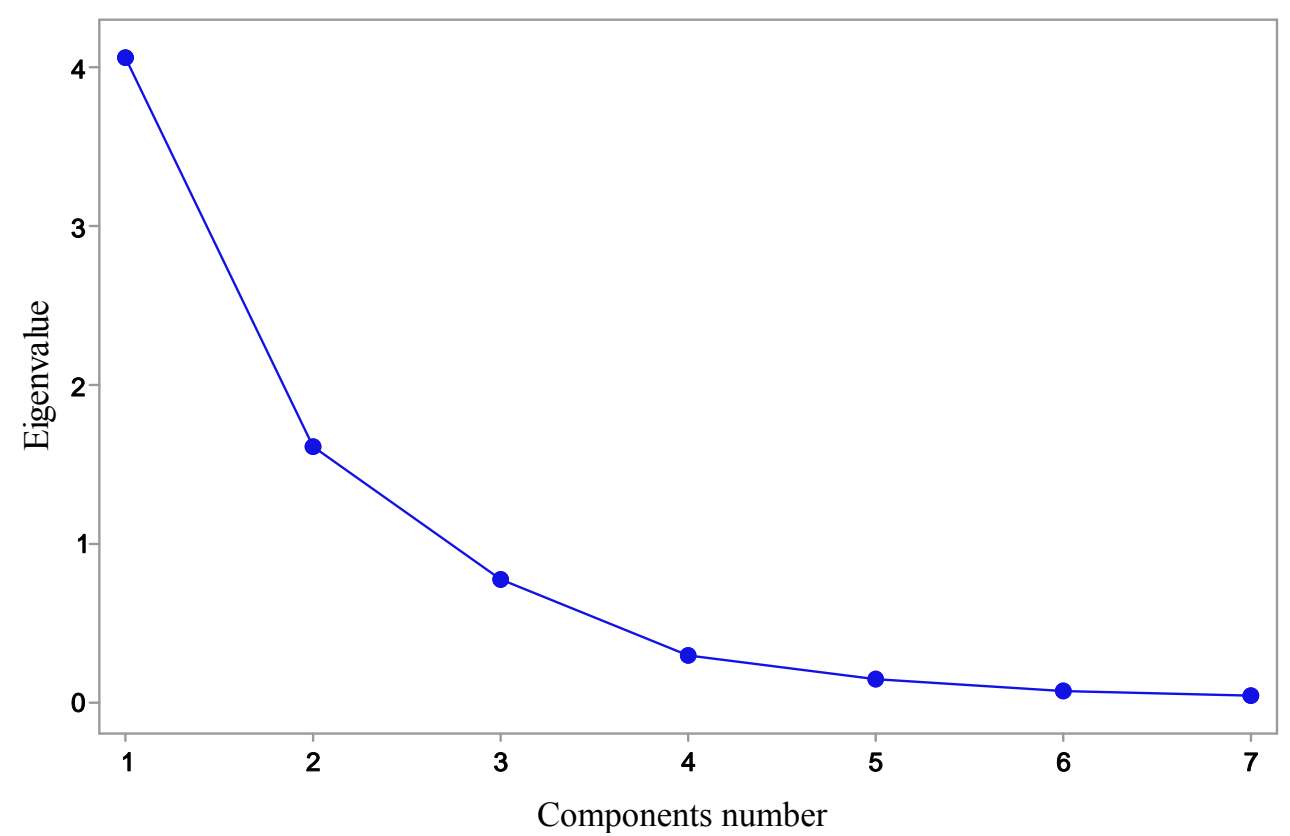

(a) 


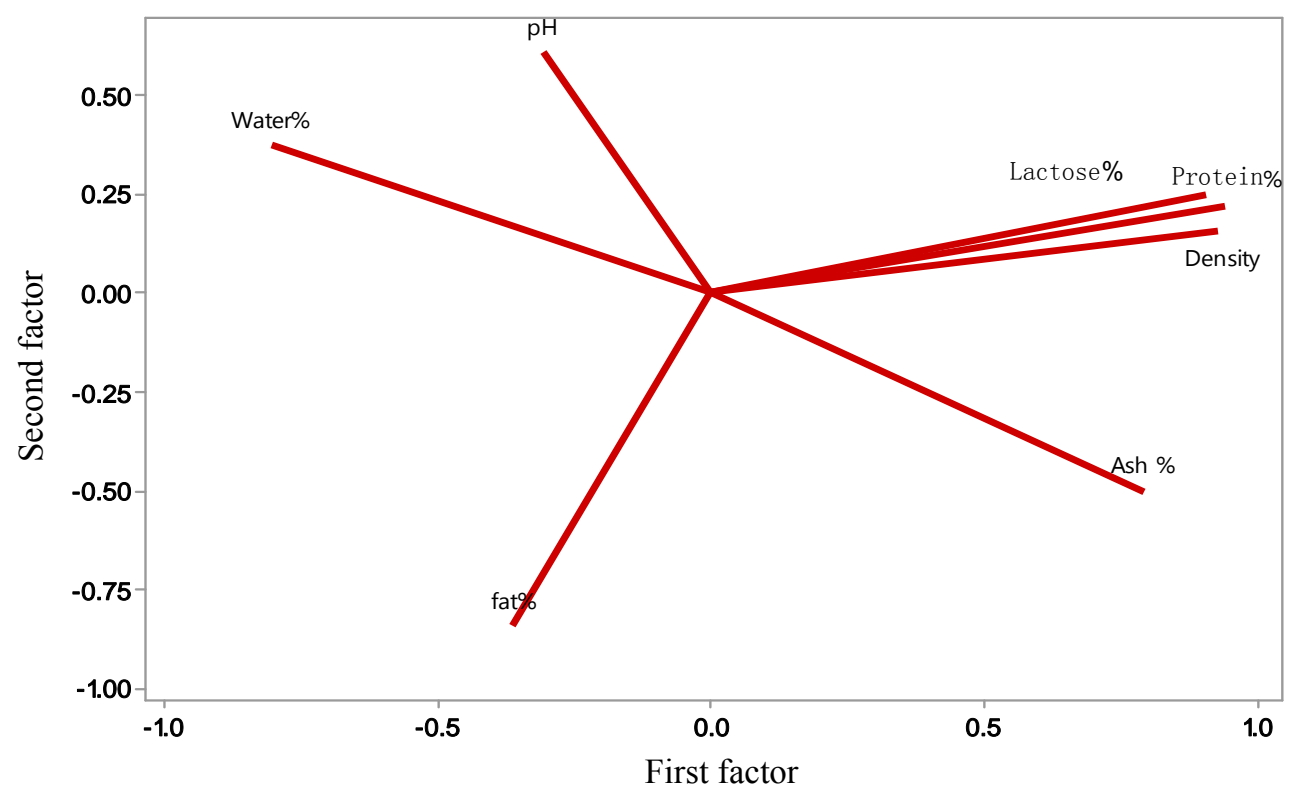

(b)

Fig. 4 Factorial analyses of milk samples.

\section{Conclusions}

In the present study, preliminary investigations were carried out to ascertain the physicochemical characteristics of cow's milk gathered in Shkodra region. The results show a relatively good quality of fresh milk with variation of physicochemical parameters according to the region where samples were gathered. These findings can serve as a base for determination of the quality of milk used directly by population or served to produce other milk products.

\section{References}

[1] Tasci, F. 2011. "Microbiological and Chemical Properties of Raw Milk Consumed in Burdur." J. Anim. Vet. Adv. 10 (5): 635-41.

[2] Walstra, P., Wouters, J. T. M., and Geurts, T. J. 2006. "Milk: Main Characteristics." In Dairy Science and Technology, 2nd ed.. Boca Raton: CRC Press, 12.

[3] Neumann, C. G., Harris, D. M., and Rogers, L. M. 2002. "Contribution of Animal Source Foods in Improving Diet Quality and Function in Children in the Developing World." Nutrition Research 22: 193-220.

[4] Varman, H. A., and Sutherland, J. P. 2001. Milk and Milk Products: Technology, Chemistry and Microbiology. USA: ASPEN Publishers Inc..

[5] Ahmad, S., Anjum, F. M., Huma, N., Sameen, A., and Zahoor, T. 2013. "Composition and Physicochemical
Characteristics of Buffalo Milk with Particular Emphasis on Lipids, Proteins, Minerals, Enzymes and Vitamins.” J. Animal and Plant Sci. 23: 62-74.

[6] Abbas, H. M., Hassan, F. A. M., Abd El-Gawad, M. A. M., and Enab, A. K. 2014. "Physicochemical Characteristics of Goat's Milk." Life Science Journal 11: 307-17.

[7] Hossain, M. B., and Dev, S. R. 2013. "Physiochemical Characteristics of Various Raw Milk Samples in a Selected Dairy Plant of Bangladesh.” Int. J. Eng. Appl. Sci. 1 (3): 91-6.

[8] Marimuthu, M., Sankar, N., Sathish, A., Vivek, S., and Mohan Raj, N. 2013. "Comparative Study on Physiochemical Quality of Raw Milk Samples Collected from Different Villages of Karur District, Tamilnadu, India." Int. J. Pharmaceut. Chem. and Biol. Sci. 3 (3): 635-8.

[9] McCarthy, O. J., Lucey, J. A., and Singh, H. 2009. "Physicochemical Properties of Milk." In Advanced Dairy Chemistry: Lactose, Water, Salts and Minor Constituents. Vol. 3. New York: Springer.

[10] AHDB Dairy. 2017. "World Milk Production." Accessed February 8, 2017. https://dairy.ahdb.org.uk/.

[11] Janštová, B., Dračková, M., Dlesková, K., Cupáková, Š., Necidová, L., Navrátilová, P., and Vorlová, L. 2011: "Quality of Raw Milk from a Farm with Automatic Milking System in the Czech Republic." Acta Vet. Brno 80 (2): 207-14.

[12] The County Council of Shkoder. 2009. "Business Guide." Accessed February,

2009. 
http://www.cci-shkodra.org/pdf/Guide_sq.pdf.

[13] INSTAT. 2012. Production of Milk by Prefecture 2012. Tiranë: Ministry of Agriculture, Food and Consumer Protection.

[14] Directorate of Agriculture and Food of Shkoder. 2012. The Advisory of Service Office, Year 2011-2012.

[15] Colorado Department of Public Health and Environment (CDPHE). 2000. Sampling-Testing: Milk and Cream Manual. Colorado: CDPHE, 5-6.

[16] Hoxha, M., and Mara, V. 2012. "Impact of Physical-Chemical Properties on Milk Coagulation Ability for Some Albanian Breeds of Cow, Sheep and Goat.” Int. J. Latest Res. Sci. and Technol. 1 (3): 234-8.

[17] Mocanu, G. D., Andronoiu, D. G., Nistor, O. V., and Botez, E. 2011. "Quality Control of Raw Cow Milk from
Galati County." J. Agroaliment. Proc. Technol. 17 (3): 303-7.

[18] Tița, M., Ketney, O., Iancu, R., and Muhammad, R. 2011. "Evaluation of Microbiological and Physicochemical Quality of Raw Milk from Sibiu Dairy Farm Province of Romania." Bulletin UASVM Agriculture 68 (2): 463-8.

[19] Zajác, P., Tomáška, M., Murárová, A., Čapla, J., and Čurlej, J. 2012. "Quality and Safety of Raw Cow's Milk in Slovakia in 2011." Potravinarstvo Slovak J. Food Sci. 6 (2): 64-73.

[20] Loshi, I., Shala, V., and Idrizi, A. 2013. "Identification of Fresh Milk in Industrial and Mountain Environment in the Region of Mitrovica and Skenderaj." In Proceedings of the 2nd International Conference Research and Education in Natural Sciences, 297. 